\title{
Interreligious education in the context of Social Psychology research on attitudes and prejudice
}

\begin{tabular}{|c|c|}
\hline $\begin{array}{l}\text { Author: } \\
\text { Martin Rothga }\end{array}$ & angel $\left.\right|^{1,2}$ \\
\hline $\begin{array}{l}\text { Affiliations: } \\
{ }^{1} \text { Institut für } \\
\text { Religionspäda } \\
\text { Evangelisch-Tץ } \\
\text { Fakultät der U } \\
\text { Wien, Austria }\end{array}$ & $\begin{array}{l}\text { gogik, } \\
\text { heologische } \\
\text { niversität }\end{array}$ \\
\hline $\begin{array}{l}{ }^{2} \text { Department } \\
\text { Theology, Uni } \\
\text { Pretoria, Sout }\end{array}$ & $\begin{array}{l}\text { of Practical } \\
\text { versity of } \\
\text { h Africa }\end{array}$ \\
\hline $\begin{array}{l}\text { Project Leade } \\
\text { Project Numb }\end{array}$ & $\begin{array}{l}\text { r: Y. Dreyer } \\
\text { er: } 2546930\end{array}$ \\
\hline $\begin{array}{l}\text { Description: } \\
\text { Prof. Dr Marti } \\
\text { participating } \\
\text { project 'Gend } \\
\text { Practical Theo } \\
\text { Formation', di } \\
\text { Dr Yolanda Dr } \\
\text { Department o } \\
\text { Theology, Facl } \\
\text { Theology, Uni } \\
\text { Pretoria. }\end{array}$ & $\begin{array}{l}\text { Rothgangel is } \\
\text { the research } \\
\text { er Studies and } \\
\text { logy Theory } \\
\text { rected by Prof. } \\
\text { eyer, } \\
\text { f Practical } \\
\text { ulty of } \\
\text { versity of }\end{array}$ \\
\hline $\begin{array}{l}\text { Correspondin } \\
\text { Martin Rothga } \\
\text { martin@rothg }\end{array}$ & $\begin{array}{l}\text { g author: } \\
\text { angel, } \\
\text { sangel.de }\end{array}$ \\
\hline $\begin{array}{l}\text { Dates: } \\
\text { Received: } 18 \\
\text { Accepted: } 15 \\
\text { Published: } 16\end{array}$ & $\begin{array}{l}\text { Fec. } 2015 \\
\text { Feb. } 2016 \\
\text { Sept. } 2016\end{array}$ \\
\hline $\begin{array}{l}\text { How to cite th } \\
\text { Rothgangel M } \\
\text { 'Interreligious } \\
\text { the context of } \\
\text { Psychology re } \\
\text { attitudes and } \\
\text { Teologiese Stu } \\
\text { Theological St } \\
\text { a3297. http:// } \\
\text { org/10.4102/ }\end{array}$ & $\begin{array}{l}\text { is article: } \\
., 2016 \text {, } \\
\text { education in } \\
\text { Social } \\
\text { search on } \\
\text { prejudice', HTS } \\
\text { Idies/ } \\
\text { udies 72(4), } \\
\text { 'dx.doi. } \\
\text { hts.v72i4.3297 }\end{array}$ \\
\hline $\begin{array}{l}\text { Copyright: } \\
\text { (C) 2016. The A } \\
\text { Licensee: AOS } \\
\text { is licensed unc } \\
\text { Creative Comr } \\
\text { Attribution Lic }\end{array}$ & $\begin{array}{l}\text { Authors. } \\
\text { IS. This work } \\
\text { der the } \\
\text { mons } \\
\text { :ense. }\end{array}$ \\
\hline Read online: & \\
\hline absin & $\begin{array}{l}\text { Scan this QR } \\
\text { code with your } \\
\text { smart phone or } \\
\text { mobile device } \\
\text { to read online. }\end{array}$ \\
\hline
\end{tabular}

Since the mid-1990s, interreligious education has become an integral component of the religious education debate. Regardless of the affective level that interreligious education seeks to provide, the desired changes in attitude and prejudice require one to take into account a diversity of research on attitude and prejudice. Accordingly, the goal of the present article is to encourage the adoption of psychological theories of prejudice with a view to the prospects they offer to interreligious education. However, because the field of psychological prejudice research is complex, we will only be discussing those theories that, firstly, reflect the present state of prejudice psychology and, secondly, are of particular relevance to interreligious education; these are cognitive theories (accentuation theory, illusory correlation theory, attribution theory), the social identity theory, and social learning theory. Emanating from this review, the article will go on to reflect different strategies of attitude change for interreligious learning.

\section{Introduction $^{1}$}

Since the mid-1990s, interreligious education has become an integral component of the religious education debate (see, among others, Engebretson et al. 2010; Schweitzer 2014; Willems 2011). A variety of theological and social developments have contributed to this trend. Among them the following three as examples: Firstly, we should highlight the opening of Christian churches and Christian theological plans to other religions as a consequence of the Second Vatican Council and the theology of religions. Secondly, over the last 30 years, the portion of Muslim citizens has grown steadily in German-speaking countries. Thus, for example, the Muslim population of Austria has grown from 8000 in 1964 (1991:158, 776; 2001:338, 988) to almost 500000 in 2011 (see Horaczek \& Wiese 2011:231). As a result, Islam has become a part of society that can no longer be overlooked, and the need for a religious education for Muslims has become evident (e.g. there are approximately 900000 Muslim students in Germany). Thirdly, though one should not prematurely speak of a resurgence of religion after German reunification, through the events of 11 September 2001, the public and political significance of religion stepped undeniably into the foreground. Likewise, 11 September 2001, signalled that interreligious education is intrinsically entwined with attitude and prejudice. Before examining the significance of psychological theories of prejudice to interreligious education, we should first consider and outline the different ways of understanding the underlying concepts of attitude, prejudice, and interreligious education.

\section{Attitude - Prejudice - Interreligious education - conceptual definitions}

Attitude is a well-studied construct in social psychology. One may define it as 'a person's predisposition or inclination to evaluate an object or its symbolic representations in a particular way or manner' (Seel 2000:118). Additionally, under the well-established attitudes model of Eagly and Chaiken, attitudes are understood as comprehensive evaluations that exhibit affective, cognitive, and behavioural components (Eagly \& Chaiken 1993). Under this model, the affective components of attitude refer to feelings or emotions; the cognitive components refer to thoughts and beliefs that are associated with a given subject; and, finally, the behavioural components refer to behaviours associated with the object under evaluation. The basic psychological need to evaluate an object, which underlies attitudes, derives from the preference for explicit answers to a topic, which are considered positive in contrast to ambiguity and confusing complexity.

1.For the German version of the following thoughts see Martin Rothgangel's Vorurteile als Integrationshindernis. Interreligiöses Lernen vor dem Hintergrund sozialpsychologischer Einstellungs- und Vorurteilsforschung, in M.Rothgangel, E. Aslan \& M. Jäggle (eds.), Religion und Gemeinschaft. Die Frage der Integration aus christlicher und muslimischer Perspektive, 2013, pp. 167-187, Vienna University Press / V\&R unipress, Göttingen. 
Attitudes thereby facilitate the formulation of judgement and the classification of topics as well as events.

Prejudice may be considered a subcategory of attitude and defined as a negative attitude toward people or groups of people. $^{2}$ From this definition emerges the negativelyevaluated aspect of 'pre-judgement', which always includes pre- and misjudgements. Similarly to attitude, prejudice may also be analysed as having cognitive (e.g. stereotype), affective (e.g. resentment), and behavioural (e.g. readiness to discriminate) components. The function of prejudice lies in the growth of one's self-esteem or sense of belonging as a result of the devaluation of another person or group. In the context of the present work, 'religious prejudice' is used in this sense, meaning that a negative attitude exists towards members of another religious group, who are devalued as a result. With that said, the chief problem of attitudes and especially prejudices is that they are often difficult to change.

This intended change of attitudes and prejudices leads us to the equally complex field of interreligious education. Without delving too deeply into the debate surrounding interreligious education, we can use the following definition by Stephan Leimgruber: 'Broadly speaking, interreligious education encompasses all (direct and indirect) perceptions concerning a religion or its adherents that may be processed and perceived by one's consciousness. [...] It always leads to a discussion of mediated religious experience. Interreligious education in the narrow sense occurs through the cosocialisation of the adherents of different religions as well as through a conversation in direct learning encounters. At the center of these encounters lies a dialog in which the interlocutors attempt to respect and understand one another'. ${ }^{3}$

One of the goals of interreligious education is to foster the tolerance and understanding of people from other religious denominations and thereby dismantle negative attitudes. From a wider religious-didactic perspective, the paradigm shift to interreligious education has led, among other things, to a situation in which the primarily cognitive handling of another religion has been supplemented with emotional aspects and practical encounters. ${ }^{4}$ This widening of scope is essential because negative attitudes towards other religions can be formed irrespective of acquired knowledge: Thus, knowledge of the five pillars of Islam does little to change the animosity of an Islamophobe towards Muslims. Generally, cognitive information alone accounts for a small part of attitude change or the elimination of prejudice. That is not to contest the value of any knowledge about religion; however,

2.Though this definition of prejudice is by no means uncontroversial in socia psychology, it nonetheless represents a widespread trend (for more detail see Rothgangel 1997:18-21)

3.Leimgruber (2007:20f). Also cited in Grethlein (2012:407), whose critical inquiries are not discussed above, despite the fact that they raise fundamental challenges to any conception of interreligious education.

4.In the context of religious education, we may observe a further widening of scope that seeks to introduce religious education studies both beyond secondary education as well as below it, down into preschool. See Edelbrock, Schweitzer \& Biesinger (2010); Edelbrock, Schweitzer \& Biesinger (2012); Hoffmann (2010); Schweitzer, Biesinger \& Edelbrock (2008). once we are confronted with the full significance of affect in religious attitudes and prejudices, we see that cognitive information on its own only accounts for the tip of the iceberg. That said, regardless of the affective level that interreligious education seeks to provide, the desired changes in attitude and prejudice do not take place in passing, but require one to take into account a diversity of research on attitude and prejudice. Accordingly, the goal of the present article is to encourage the adoption of psychological theories of prejudice with a view to the prospects they offer to interreligious education. However, because the field of psychological prejudice research is complex, we will only be discussing those theories ${ }^{5}$ that, firstly, reflect the present state of prejudice psychology and, secondly, are of particular relevance to interreligious education. ${ }^{6}$

\section{Religious prejudice as 'a categorisation problem' (Cognitive theories)}

In the late 1960s psychology underwent the so-called cognitive revolution. In prejudice research, psychological explanatory models like scapegoat theory or studies about the authoritarian personality were largely supplanted by theories $^{7}$ that ultimately resituated the emergence of prejudices in 'natural' processes of thought and perception.

\section{Accentuation Theory}

It is well known from perception psychology that a person can absorb and process only a portion of the sensory information available to him or her in the surrounding world. This makes the development of 'reduction strategies' especially necessary (see Codol \& Leyens 1990:92). Accordingly, social prejudices should not be merely understood as 'false' judgements. Rather, they represent the natural and inevitable consequence of the processing of social stimuli and provide guidance in a complex outer world (see Six 1988:327; Tajfel 1969:82).

In the categorisation of people, a decisive role is played by physical (e.g. body size, hair colour, gender) and social (e.g. ethnic and religious membership) traits. We may understand social prejudice as an assumed correlation between a particular category (e.g. Italian) and one or several traits (e.g. body size). ${ }^{8}$ This leads, however, to the accentuation of

5.For more detail, see Rothgangel (1997). It is worth remarking that comparable psychological theories of prejudice are discussed in J. Lüddecke's work (2007). It is psychological theories of prejudice are discussed in J. Lüddecke's
only cognitive theories that are insufficiently addressed by him.

6.In any case, the limitation of the following observations is that psychological theories of prejudice work only on the intrapersonal, interpersonal and intergroup explanatory levels, leaving the social level more or less out of the picture (see Lüddecke (2007:112-125).

7.Scapegoat theory (see Rothgangel 1997:86-88; as well as the brief mention of it in Aronson, Wilson \& Akert (2008: 448f), including the work done by Bierhoff $(2006: 176 ; 360)$ and the studies of the authoritarian personality (see Adorno et al. 1950) are not discussed here. Irrespective of their former significance, these are considered to be outdated and they therefore offer little insight as far as interreligious education is concerned.

8.'The categorisation of physical or social aspects of the environment is based on the application of particular criteria in order to distribute a collection of items into more or less extensive groups which differ across the given or similar criteria, but which however, resemble the same (or similar) criteria within each grouping' (Tajfel 
differences between the traits of different categories - that is traits that mark differences are emphasised or exaggerated (Six 1983:330). In practice this means that a person's membership of different groups (e.g. category A: Italian; category B: Swedish) can alone lead to an overemphasis on the perception of differences ('The Swedes are larger than the Italians'). Numerous empirical studies demonstrate accentuation effects in physical as well as social stimuli (see Stroebe \& Insko 1989:24).

Because of the complexity of the social environment, accentuation effects related to social prejudice arise primarily as a result of social influence and less as a result of observation (Stroebe \& Insko 1989:25). This, in turn, suggests that accentuation theory lends itself more to studying macro factors of socialisation and learning theory. The founder of accentuation theory, $\mathrm{H}$. Tajfel, later extended his explanatory model with the social identity theory, in which he supplemented his use of certain thought processes to explain prejudice formation with human motives and needs. Applied on its own, accentuation theory can explain why differences between two groups are emphasised. Its limitations, however, lie in its inability to explain why other groups are frequently devalued in relation to one's own group.

Immediate prospects for interreligious education: Strictly speaking, accentuation theory tells us that the juxtaposition of two religions alone suffices for people to accentuate the differences in the traits between these two religions. On its own, this effect becomes highly relevant when religious education deals with the subject of other religions. Specifically, accentuation is worth considering during the planning of teaching and learning processes in order to avoid the unconscious teaching of prejudice. We will address the specific strategies for doing so-strategies of decategorisation, recategorisation, and mutual differentiation - in the last section of this article.

\section{Illusory correlation theory}

The illusory correlation theory proves useful when dealing with social minority groups and social prejudice formation as a result of observation (see Meiser 2008). Its basic thesis is as follows: The joint occurrence of two 'special' stimuli or objects leads to an illusory correlation (see Hamilton \& Sherman 1989:60) - that is the assumption of a mutual relationship between two objects, which does not exist in reality or exists to a much lesser extent than perceived (see Tajfel 1982:47).

We can turn to the following example to elucidate this further (see Hamilton \& Sherman 1989:61f): Research participants were given sentences to read that described the everyday behaviour of people from two groups (group A, group B). A majority $(69 \%)$ of these statements expressed a desirable behaviour, while a smaller portion $(30 \%)$ expressed an

(footnote continues)

1982:44). The term social categorisation is justified in two ways: Firstly, it deliberately makes reference to social objects, and, secondly, the formation of the categorisation is itself socially conditioned (see also Stroebe \& Insko 1989:24) undesirable one. Both groups were assigned the same proportion of undesirable versus desirable statements; however, group A was represented twice as frequently as group B and therefore acted as the majority group (26 total statements), while group B acted as the minority (13 total statements). According to the illusory correlation theory, undesirable behaviour draws attention because of its lower incidence and thereby becomes a 'special' stimulus event. In this experiment a second 'special' stimulus event was represented by group B, because, as a minority group, it was less represented than group A. After a certain amount of time, research participants were asked how they perceived the proportion between desirable and undesirable behaviours for each group. The results of this experiment showed convincingly that the correlation between the two 'special' stimuli (i.e. the correlation between undesirable behaviour and group B) was overvalued: Research participants disproportionately ascribed undesirable behaviour to group B. A similar effect was not observed towards group A. ${ }^{9}$

The consequences of these findings are wide-reaching. In the context of this theory, we can explain the subjective exaggeration of group B's undesirable behaviour as arising because 'negative behaviour by minority group members is overrepresented in memory and judgement' (Tajfel 1982:47). Furthermore, we should keep in mind that beyond the factor of incidence, there may be further factors that mark a stimulus as 'special'. Generally, we can say that any factor that increases the attention that a stimulus receives can become the basis for an illusory correlation between that stimulus and a further 'special' stimulus (see Tajfel 1982:71). The illusory correlation theory is, therefore, above all relevant in our scholarly efforts to explore, explain, and understand the formation of prejudice-related behaviour.

Numerous studies that have been conducted since Chapman's initial 1967 work further corroborate the illusory correlation thesis (see Tajfel 1982:69) and other cited publications). There have been several experiments, however, that showed an exception to the rule: An illusory correlation does not occur, for example, if such a correlation would lead to the devaluation of one's ingroup (see Stroebe \& Insko 1989:27; Tajfel 1982:74).

Immediate prospects for interreligious education: This last point deserves attention in the context of interreligious education. For example, in his Parable of the Olive Tree, Paul offers an example applicable to the handling of Judaism in the context of religious education: He warns Christian gentiles against arrogance towards the 'unbelieving' Jews by reminding them that the roots support the grafted branches (i.e. the Christian gentiles) and not vice versa (Rm 11:18 New International Version). He goes on to provide the following warning against devaluation: 'For if God did not spare the natural branches, he will not spare you either' (Rm 11:21 New

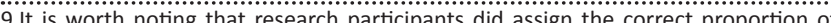
che 1989.62). This can a to be mill 1989.62). This can also be considered positive evidence of the illusory correlation theory, as the desirable behaviour does not represent a distinctive event in this experiment. 
International Version). In principle, the illusory correlation theory can explain why religious minorities might draw prejudice against themselves simply as a result of such 'natural' errors of categorisation.

\section{Attribution theory}

The last cognitive-psychological explanatory model of religious prejudice that we should discuss is attribution theory. Its merit lies in relating sociocultural factors to insights with regard to cognitive psychology (see Bergmann 1988:281). This theory is based on three premises:

1. The impressions that people have of other people give rise to and/or lead to causal explanations for others' behaviour.

2. This behaviour is attributed ('ascribed') either to external or internal factors.

3. Before attributing the behaviour in question to personal characteristics, one takes into account that the person could have behaved otherwise (the individual, in other words, always has a choice; Bergmann 1988:281).

According to attribution theory, social factors such as education level, unemployment rate, etc. can also be attributed to discrete or (!) group-specific motives. In this sense, the relatively high unemployment rate of African Americans in the United States (to use an example) might lead to the notion that African Americans are stupid and lazy (Bergmann 1988:281f). Generally, we might conclude that the attribution of traits to another group, whether in a positive or negative sense, is performed on a more polarised and undifferentiated basis than to one's own group. Likewise, the positive behaviour of the other group is attributed to external factors, whereas the positive behaviour of one's own group is attributed to personal characteristics; the perception of negative behaviour entails a direct reversal of this attribution process (see Bergmann 1988:281).

According to this theory, the development and dissemination of prejudices can be attributed to the fact that differences between groups are not based on external circumstances, but rather on pseudo-psychological arguments about the characteristics of the other group. In this sense, one can 'explain' - or, to put it more precisely, justify - the social disadvantages of minorities; the discrepancy between one's own value system and the perception of reality is thereby mitigated by the fact that, with the help of the attribution mechanism, one may deny one's own responsibility towards the disadvantaged social situation of minorities (see Bergmann 1988:280f).

\begin{tabular}{|l|l|l|}
\hline & $\begin{array}{l}\text { Another group (e.g. dark- } \\
\text { skinned Americans) }\end{array}$ & $\begin{array}{l}\text { Own group (e.g. light- } \\
\text { skinned Americans) }\end{array}$ \\
\hline $\begin{array}{l}\text { Positive behaviour } \\
\text { (e.g. graduating } \\
\text { school) }\end{array}$ & $\begin{array}{l}\text { External factors (affirmative } \\
\text { action) }\end{array}$ & Personal traits (intelligent) \\
\hline $\begin{array}{l}\text { Negative behaviour } \\
\text { (e.g. being } \\
\text { unemployed) }\end{array}$ & $\begin{array}{l}\text { Personal traits (stupid and } \\
\text { lazy) }\end{array}$ & $\begin{array}{l}\text { External factors (high } \\
\text { national unemployment } \\
\text { rate) }\end{array}$ \\
\hline
\end{tabular}

FIGURE 1: Example of Attribution Theory.
Immediate prospects for interreligious education: Attribution theory is not only of interest because it draws attention to the undifferentiated treatment of other groups: One could view this issue through, for example, the sweeping accusation of 'works righteousness' levelled against 'the' Jews or 'the' Muslims. The theory also explains from a social psychological perspective why societal differences such as those that currently exist between Christians and Muslims in Germany (e.g. education) are less externalised to structural factors (the general favouring of children from families with higher education) and blamed primarily on the (prescribed) 'character traits' of Muslims. Attribution theory is therefore also a useful and/or convenient and/or suitable and/or valuable and/or worthwhile explanatory model for religious prejudice formation.

In summary, it must be remembered with regard to these cognitive theories that prejudice cannot be attributed to the cognitive processes of accentuation, illusory correlation, or attribution alone. Instead, it is very likely that each particular prejudice arises multifariously from a diversity of processes (see Bergmann 1988:280f). In the context of these approaches, social prejudices may be understood as cognitive categories that are necessary for orienting oneself within a social environment (see Stroebe \& Insko 1989:5). As a result, during an analysis of prejudice, motivational as well as functional factors remain largely concealed. Accordingly, H. Tajfel, one of the pioneers of cognitive psychology, refers in his later modified view of 'social identity theory', to an essential difference between social prejudice and other cognitive categories: As a rule, prejudices about outgroups are less positive in relation to the ingroup - that is, a purely cognitive explanation does not enable us to interpret adequately an ethnocentric attitude that is widely observed among a group of people (see Stroebe \& Insko 1989:5).

\section{Religious prejudice as a problem of identity (Social identity theory)}

When it comes to the so-called 'conflict theories', we may distinguish between the realistic conflict theory (Campbell; Sherif) and the social identity theory (Tajfel; Turner; see Stroebe \& Insko 1989:14). According to the realistic conflict theory, political, economic, etc. conflicts between groups result in a perception of threat, the consequence of which is again ethnocentrism - that is, enhanced solidarity within the ingroup and a devaluation of the competing outgroup (see Stroebe \& Insko:1989:14).

For the analysis of religious prejudice, however, the social identity theory ${ }^{10}$ deserves more attention, as it provides well founded corrections and additions to the realistic conflict theory. Firstly, the perception of belonging to one of two groups alone can lead one to prefer one's own group and disadvantage the other group. Secondly, not every group

10.Petersen (2008) and Petersen \& Blank (2008) offer an up-to-date overview of this theory. For the significance of this theory, see Petersen \& Blank (2008): 'The minimal group paradigm has been the dominant research paradigm in social discrimination research during the last four decades' (p. 200). 
conflict needs to lead to ethnocentrism, because an effective antidote might be, for example, the provision of an institutional framework that mediates competition between groups. Thirdly, conflicts might arise not only over 'physical' resources, but also over social prestige and social status (see Stroebe \& Insko 1989:14). With the help of social identity theory, these criticisms may be integrated into a self-contained explanatory model. One could say that the inherent human desire for a positive social identity represents the Archimedean fulcrum point of this theory (Tajfel 1982:101-103). ${ }^{11}$

This situation can be illustrated by means of the 'minimal intergroup' experiments. ${ }^{12}$ In these experiments, research participants were aware of their own group membership and the group membership of those among whom they were asked to distribute money. However, research participants knew the individuals of the ingroup and the outgroup only through code numbers (Tajfel 1982:118f). In one such experiment, three 'money distribution strategies' were available to choose from: the first entailed a maximum shared win for both groups; the second, maximum profit for the ingroup; and the third, a maximum difference between the groups in favour of the ingroup (Tajfel 1982:119). Tajfel justified these requirements as follows: There was no externally defined conflict in our experiments; if there was competition (i.e. actions aimed at differentiating between the groups in favour of one's own), then it was actively introduced to the situation by the participants themselves as soon as the researchers introduced the concept of a group. Research participants were never together in a 'group'; they did not interact, nor did they know who belonged to the outgroup or to their ingroup; there was no explicit social pressure to act in favour of their own group, nor was it in the interest of the research participants to grant the members of their own group more money. On the contrary, had they consistently pursued a strategy of maximum joint profit, they would all have received more money from the researcher' (Tajfel 1982:124). Nevertheless, the third 'money distribution strategy', the one providing maximum difference in favour of the ingroup, predominated. The minimal intergroup experiments therefore reveal a need to focus on positive ways to distinguish oneself from other groups (see Tajfel 1982: 121-125). This striving for a positive trait manifests itself in various social and cultural interactions (see Tajfel 1982:126).

Because the status of the ingroup represents an important determinant of social identity, low social status motivates the members of a group to join another group of higher status or to improve the status of their own group (see Tajfel 1982:103). Conversely, members of the 'superior' group seek to defend their status against groups that threaten or appear to threaten it, and justify their status anew if they see it associated with a conflict of values (e.g. if the higher status is based on unjust

11.Tajfel (1982) defines social identity as "that part of an individual's self-image [ that is derived from the knowledge of his or her membership in social groups and from the value and emotional meaning that this membership carries' (p. 102).

12.The so-called 'minimal intergroup experiments' were conducted to determine the minimal conditions under which an individual would demonstrate a noticeable difference in his or her behaviour in favour of an ingroup versus an outgroup (see Tajfel 1982:118) prejudices) (see Tajfel 1982:132f). Under the social identity theory, prejudices may, for instance, be viewed as an effective means to present one's own group in a better light or to justify its unfair advantages. The purpose of such measures lies, in the former case, in the indirect improvement of the ingroup's status and, in the latter case, in the justification of the lower social status of the outgroup.

Immediate prospects for interreligious learning: In summary, we may consider social identity theory, as it applies to religious prejudice, to be a sophisticated and highly developed conceptual framework. Because the mere perception of membership in a different group leads a priori to the favouring of one's own religion and the discrimination against another religion, it is only reasonable according to social identity theory that prejudice against other religions contributes to securing one's own religious identity. In contrast to the cognitive-structural theories and social learning theory, social identity theory favours motivational reasons for social prejudice formation. In the last section of this work, we will discuss the link between social identity theory and contact theory, one of the most thoroughly-researched approaches to attitude change. We will also look at studies that have been conducted at school-level, which might hold special relevance for interreligious education precisely because of the way in which they structure learning encounters.

In conclusion, it should nevertheless be stressed that social identity theory is not a 'catch-all' framework for religious prejudice. ${ }^{13}$ It does not, therefore, take into account the role that, for example, parents or other agents of socialisation the importance of which is discussed below - play in prejudice formation.

\section{Religious prejudice as socialisation problem (Social learning theory)}

Education plays an important role in maintaining subcultures and therefore also in the passing on of religious prejudice. Children whose parents espouse antisemitic or islamophobic values learn these prejudices from their parents. It is primarily educational content that is responsible for prejudice formation and dissemination, not, for example, an authoritarian style of parenting (see Weiss 1986:62). In contrast to scapegoat theory, proponents of social learning theory (e.g. Bandura; Eagly) do not presuppose a motive which leads to the devaluation of other groups. Social prejudices arise either from the observation of existing differences between different social groups or from social influences that one may be exposed to in the course of one's life through parents, peers, school, and the mass media (see Stroebe \& Insko 1989:15).

According to social learning theory, one's perception of a group is formed through one's exposure to behaviour specific to that group. Such behaviour is, however, highly contingent

13.The current state of social identity theory, as well as its limitations and prospects for further development, are thoroughly discussed in Zick (2008). 
upon the relevant social roles that might be at play (see Stroebe \& Insko 1989). A person who repeatedly observes a specific behaviour among a group of people will very likely adopt the view that the traits evinced in this situation are typical for the given group (see Stroebe \& Insko 1989:16). Accordingly, many ethnic and racist prejudices are based on the differences that exist between groups within a social structure (see Stroebe \& Insko 1989). Here, it bears stressing that the observer is never confronted with all of the group's traits but only a very specific selection of them.

Such prejudices are ultimately passed down by agents of socialisation such as family, peers, schools, and the mass media. Because racial, ethnic, and gender prejudices are acquired at a relatively early stage of life (from around the age of 4$){ }_{1}^{14}$ parents play a very significant role in this process. A child learns these prejudices, on the one hand, through the linguistic information it receives from its parents and, on the other, through the learning model provided by the parents' behaviour (see Stroebe \& Insko 1989:16). The consequences that parents experience as a result of their own demonstrated behaviour are major determinants for whether the child engages in or avoids the same behaviour.

The less education a person has, the less likely it is that he or she will understand a complex phenomenon - such as his or her social environment - in intellectual terms. Likewise, a person will be less likely to accept ambiguity. Selznick \& Steinberg (1969) refer to this situation as simplicity and use surveys to demonstrate that simplicity steadily decreases with a rise in education level. ${ }^{15}$ It is worth noting at this point that a lack of education is also accompanied by a lack of ethical sensitivity, which leads to the acceptance of attitudes that include inhumane or intolerant ideas (see Selznick \& Steinberg 1969:141f). Accordingly, a rise in 'simplicity' is accompanied by a significant increase in the incidence of antisemitic attitudes. ${ }^{16}$ Simplicity, however, is far from a purely cognitive phenomenon. It also has an impact on an emotional level, because lacking cognitive differentiation and accepting intolerant opinions entails further psychological consequences (see Selznick \& Steinberg 1969:142 \& 168).

Immediate prospects for interreligious learning: The analysis of religious prejudice benefits from the inclusion of social learning theory through a significant expansion of perspective: Here the importance of social influences and subcultural values becomes generally identifiable in a manner that considers the coexistence of different cultures and subcultures. Religious prejudices are therefore acquired by the 'completely normal' process of socialisation in which

14.Ethnic prejudices are acquired between the ages of three and five (see Aboud 1998:43). Further discussion of this issue may be found in Bergmann (1988:280 note 70); for an illustrative example with third graders, see Aronson et al. ( $2008: 430 f)$

15.Lower 'simplicity' is found among $9 \%$ of people with only a primary education $18 \%$ with a high school education, $34 \%$ with some college education and $49 \%$ with a full college education. Conversely, higher 'simplicity' is found among $51 \%$ of . some college education and $9 \%$ with a full college education (see Selznick \& Steinberg 1969:141).

16.'As simplicity goes from low to medium to high, the proportion of antisemitism rises from 17 to 39 to 64 percent' (Selznick \& Steinberg 1969:142f). one grows up within a culture with very specific religious prejudices. ${ }^{17}$ In this context, there is no longer a need to pose the question of why a person acquires religious prejudices. Rather, the important question becomes which forces can make a person resistant to religious prejudice within a prejudiced culture (Selznick \& Steinberg 1969:169). Numerous surveys have confirmed that education has an immunising effect on antisemitism: The more educated a person is, the less likely they are to espouse, for example, antisemitic prejudices.

\section{Strategies of attitude change for interreligious learning}

Our discussion of the various psychological theories shows us that none of these theories can generally explain the origin and function of religious prejudices. To put it succinctly, we find that in the context of cognitive theories, religious prejudice functions as a categorisation problem; in the context of social identity theory, it functions as an identity problem; and in the context of social learning theory, it functions as a socialisation problem. Meanwhile, in the field of psychology itself, we can observe a particular trend to take integrative explanatory models increasingly into consideration. ${ }^{18}$

Nevertheless, at this point, it is worth drawing attention to another conundrum. In the fields of attitude and prejudice psychology, we can currently observe the predicament that evidence-based theories of attitude change or prejudice reduction ${ }^{19}$ were developed relatively independently of the theories of prejudice formation and function discussed above. The elimination of this research deficit has even been described as the most exciting challenge ${ }^{20}$ of the coming decades. This 'gap' notwithstanding, we can derive specific evidence-based theories of attitude and prejudice from the enumerated theories, and formulate conditions under which interreligious education can contribute to the changing of negative religious attitudes.

\section{Strategies to combat the categorisation problem}

With regard to the categorisation problem, there are, above all, three strategies that are being discussed in social

17.Selznick \& Steinberg (1969:169). In the same work, the authors cite a relevant quote from Robin M. Williams Jr.: 'Prejudices against minority groups are learned. quote from Robin M. Williams Jr.: 'Prejudices against minority groups are learned. They may reflect deep, irrational, personality processes, but they need not. [... There is the real possibility that [...] prejudices may be learned in the same way that we learn that the world is round (or flat, or held up on the back of a giant turtle) (p. 137, note 2 ).

18.A glance at Henri Tajfel's work can illustrate this trend. In Gruppenkonflikt und Vorurteil [Group conflict and prejudice] (1982), Tajfel discusses the thought processes that led him from accentuation theory to social identity theory. The following quote reflects his integration of motivational and cognitive factors: 'The interaction between socially derived value differences on the one hand and cognitive mechanics of categorisation on the other is especially important to any social distinction between 'us' and 'them" ( $p .101)$. This view mirrors in many ways the integrated explanatory model of Stroebe \& Insko (1989:28-30).

19.See, for example, Oskamp (2000a, 2000b). Much discussed is the contact hypothesis (see Pettigrew \& Tropp 2000; Stürmer 2008)

20.Forgas, Cooper \& Crano (2010:13).In comparison to other areas of prejudice research, there have been relatively few studies on prejudice reduction. Nevertheless, there has been a wide range of research since the mid-1980s that investigates the possibility of arriving at an empirical synthesis of contact theory investigates the possibility of arriving at an empic
and social identity theory (see Brewer 2000:165). 
psychology research on prejudice. Problematic category mappings between the ingroup ('us') and the outgroup ('them') should be changed in a manner that 'either decreases the general probability of categorising one's interaction partner on the basis of their group membership (decategorisation), alters the definition of the ingroup in a way that includes the former outgroup in the 'us' (recategorisation), or positively alters the valuation associated with the determination of otherness (reciprocal differentiation)' (Otten \& Matschke 2008: 292).

In the context of interreligious education specifically, decategorisation entails, for example, no longer categorising one's Muslim neighbour as a Muslim, but through personal friendship as, again for example, the helpful Sinan (see Otten \&Matschke2008:293). Afurther form of decategorisation is cross-categorisation. Here, the existing categorisation between, for example, Christians and Jews is not simply negated, but is in some way relativised or 'crisscrossed' wherein, in addition to the divisive differences (e.g. the doctrine of justification), the overarching similarities between Christianity and Judaism (e.g. their common roots and hopes for the future) are also exposed. With regard to recategorisation, we can consider the example of the original ingroup, Christianity, and the two outgroups of Judaism and Islam, in which all three religions are recategorised under the comprehensive label of Abrahamic religions, thereby becoming 'part of a new, superordinate, common ingroup' (Otten \& Matschke 2008:294). In doing so, both de- and recategorisation presuppose that the original 'distinction between ingroup and outgroup is abandoned, either in favour of a personalized view of the interaction partners, or in favour of a new, broader categorical perception' (Otten \& Matschke 2008:294). However, only particular categorisations lend themselves to this kind of relativisation. It is possible that religious members facing categorisation might perceive, in the above-mentioned strategies, a threat to their identities and refuse to implement them. In the reciprocal differentiation model, 'the striving for a positive social identity [is exploited] to improve intergroup relations constructively. By joining the ingroup and outgroup in a positive interdependence - in which each group adopts distinct and simultaneously complementary roles - the groups could begin to appreciate each other without having to give up their need for positive distinctiveness' (Otten \& Matschke 2008:295). By way of example, Christianity, Judaism, and Islam could, in their respective majority societies, collaborate on complementary contributions towards peace education, which none of the three could accomplish on their own, especially from positions of minority.

\section{Strategies to combat the social identity and socialisation problems}

As we have already mentioned above, encounters between religions serve as a constitutive part of interreligious education. Here, the contact hypothesis that arose from the research of G. Allport (1954) is especially noteworthy, because it is one of the most studied socio-psychological theories of attitude change. Furthermore, research since the 1980s has focused on linking the contact hypothesis with social identity theory (see Brewer 2000:165).

That is not at all to say that prejudices between two groups can be eliminated with encounters per se. In the early 1950s, Allport managed to resolve contradictory empirical findings by specifying the following conditions under which contact between different groups contributed to prejudice reduction, namely, (1) shared objectives, (2) intergroup cooperation, (3) equal status between groups, and (4) the support of authorities, norms or laws. Pettigrew adds to this by emphasising that the contact (5) should provide the opportunity to develop friendships across group boundaries (Stürmer 2008:284). The most important thing is, therefore, to set overarching goals (e.g. integrity of creation) that can be reached exclusively through joint cooperation between the two groups - one in which the competitive aspect is entirely excluded. In doing so, it is important to ensure that the groups do not recreate the status differences that characterise the groups outside the given contact situation (see Stürmer 2008:285). We may recognise elements of social learning theory in this conditioning factor. The same also applies to the significance of official (ecclesiastical) pronouncements which oppose discrimination against other religions and stand up as much for tolerance as for a reconciled diversity. Finally, we can also take advantage of empirical studies which show that friendships - in this case between, for example, Christian and Muslim students - can lead to the fundamental elimination of prejudices against another religion (see Stürmer 2008:285).

Pettigrew, a student of Allport, identifies four processes that contribute under 'optimal' contact conditions to a change in attitudes towards outgroup members, namely, (1) acquisition of knowledge, (2) change in behaviour, (3) building of bonds and (4) the revaluation of the ingroup (Stürmer 2008:286). Moreover, Pettigrew examines contact theory with a view to linking it to the above-discussed strategies of de- and recategorisation, as well as reciprocal differentiation (see Stürmer 2008:287f): For the first phase, that of initial contact, he proposes personalisation and therefore decategorisation. Emphasising the individual may increase the participants' willingness to engage and can, during the cumulative time of contact, lead to the development of friendly relations based on common individual interests that transcend different group membership. For the second phase, that of established contact, Pettigrew proposes reciprocal differentiation: 'Once the foundation for a friendly and cooperative approach has been prepared during the initial contact phase' (Stürmer 2008:287) the participants should work on acquiring knowledge of differences (in the case of interreligious education this could be, for example, religious creeds and rites) and respecting one another. In the last phase, that of the combined group, participants should work increasingly on detecting commonalities, which could ultimately lead to a recategorisation. That being said, it should be noted that this phase model is not yet based on empirical evidence. 
Nevertheless, the contact hypothesis itself is an empirically well supported theory (see Wagner \& Farhan 2008:277). It has been used in the United States to develop preventive measures in schools. The focus of these programs is cooperative group instruction that differs from traditional group work in that 'the students work together in ethnically and proficiently heterogeneous small groups. The members of a small group receive different information, so that the small groups can do their assignments only if every small group member contributes his or her specific skills' (Wagner \& Farhan 2008:277). Applied to interreligious education, such a study would have the following design. Small groups of four to six children of different religions, denominations, or beliefs are formed, in which each member is responsible for a special area (e.g. creation from the perspective of Islam; creation from the perspective of Christianity, etc.). The groups spend 80 minutes per week working together. Moreover, about 40 minutes per week is also spent in so-called expert groups in which, for example, all the Muslim students who have been charged with the topic of creation in Islam can exchange information. In the original study with students from different ethnic groups, 'every two weeks [...] a quiz was conducted, and the grade of each child resulted from their individual performance and the average team performance' (Wagner \& Farhan 2008:280). Applied in experimental classes, such measures (which are ultimately based on Allport's conditions for intergroup contact) led to a significant and positive effect in attitude change in comparison to the control groups (Wagner \& Farhan 2008:280). Nevertheless, further empirical studies aimed at interreligious education and based on social psychology research remain a desideratum of religious education research.

\section{Acknowledgements Competing interests}

The author declares that he has no financial or personal relationships which may have inappropriately influenced him in writing this article.

\section{References}

Aboud, F.E., 1998, Children and prejudice, Blackwell, London.

Adorno, T.W., Frenkel-Brunswik, E., Levinson, D.J. \& Sanford, N.R., 1950, in M Horkheimer \& S.H. Flowerman (eds.), The authoritarian personality: Studies in prejudice, Harper \& Brothers, New York.

Allport, G., 1954, The nature of prejudice, Addison-Wesley, Cambridge, MA.

Aronson, E., Wilson, T.D. \& Akert, R.M., 2008, Sozialpsycholologie [Social psychology], Pearson Deutschland, Munich.

Bergmann, W., 1988, 'Attitude theory and prejudice', in W. Bergmann (ed.), Error without trial: Psychological research on antisemitism, pp. 271-301, de Gruyter, Berlin.

Bierhoff, H.W., 2006, Sozialpsychologie. Ein Lehrbuch, [Social psychology. A textbook] 6th edn., Kohlhammer, Stuttgart.

Brewer, M.B., 2000, 'Reducing prejudice through cross-categorization: Effects of multiple social identities', in S. Oskamp (ed.), Reducing prejudice and discrimination, pp. 165-183, Lawrence Erlbaum Associates, London.

Codol, J.P. \& Leyens, J., P., 1990, 'Soziale Informationsverarbeitung' [Social information processing], in W.E. Stroebe, M.E. Hewstone, J.P. Codol \& G.M.E. Stephenson (eds.), Sozialpsychologie. Eine Einführung [Social psychology. An introduction] pp. 89-111, Springer, Berlin.

Eagly, A.H. \& Chaiken, S., 1993, The psychology of attitudes, Harcourt, Brace, \& Janovich, Fort Worth, TX.
Edelbrock, A., Schweitzer, F. \& Biesinger, A. (eds.), 2010, Wie viele Götter sind im Himmel? Religiöse Differenzwahrnehmung im Kindesalter [How many gods are there in the sky? The perception of religious differences during childhood], there in the sky?
Waxmann, Münster.

Edelbrock, A., Schweitzer, F. \& Biesinger, A. (eds.), 2012, Religiöse Vielfalt in der Kita. So gelingt interreligiöse und interkulturelle Bildung in der Praxis [Religious diversity in daycare. This is how interreligious and intercultural education works in praxis], Cornelsen Scriptor, Berlin.

Engebretson, K., Souza, M., de, Durka, G. \& Gearon, L. (eds.), 2010, Internationa handbook of inter-religious education. Part 1, Springer, Dordrecht.

Forgas, J.P., Cooper, J. \& Crano, W.D., 2010, 'Attitudes and attitude change. An introductory review', in J.P. Forgas, J. Cooper \& W.D. Crano (eds.), The psychology of attitudes and attitude change, pp. 3-17, Taylor \& Francis, London.

Grethlein, C., 2012, 'Interreligiöses Themen' [Interreligious topics], in M. Rothgangel, G. Adam \& R. Lachmann (eds.), Religionspädagogisches Kompendium [Religiouspedagogical compendium], pp. 403-415, Vandenhoeck \& Ruprecht, Göttingen.

Hamilton, D.L. \& Sherman, S.J., 1989, 'Illusory correlations: Implications for stereotype theory and research', in D. Bar-Tal, C.F. Graumann, A.W. Kruglanski \& W. Stroebe (eds.), Stereotyping and prejudice. Changing conceptions, pp. 59-82, Springer, New York.

Hoffmann, E., 2010, Interreligiöses Lernen im Kindergarten? Eine empirische Studie zum Umgang mit religiöser Vielfalt in Diskussionen mit Kindern zum Thema Tod
[Interreligious education in kindergarten? An empirical study for the handling of [Interreligious education in kindergarten? An empirical study for the handling of
religious diversity in discussions with children on the topic of death], LIT, religious
Münster.

Horaczek, N. \& Wiese, S., 2011, Handbuch gegen Vorurteile. Von Auschwitzlüge bis Zuwanderungstsunami [Manual against prejudice. From Auschwitz-denial to immigration-tsunami], Czernin, Vienna.

Leimgruber, S., 2007, Interreligiöses Lernen [Interreligious education], 2nd edn., Kösel, Munich.

Lüddecke, J., 2007, Ethnische Vorurteile in der Schule. Entwicklung eines Präventivkonzepts im Rahmen Interkultureller Pädagogik [Ethnic prejudice in school. The development of a preventive approach in the context of intercultural pedagogy], Iko, Berlin.

Meiser, T., 2008, 'Illusorische Korrelation' [Illusory correlation], in L-E Petersen \& B. Six (eds.), Stereotype, Vorurteile und soziale Diskriminierung. Theorien, Befunde und Interventionen [Stereotypes, prejudices and social discrimination. Theories, findings and interventions], pp. 53-61, Beltz, Basel.

Oskamp, S., 2000a, 'Multiple paths to reducing prejudice and discrimination', in S. Oskamp (ed.), Reducing prejudice and discrimination, pp. 1-19, Lawrence Erlbaum Associates, London.

Oskamp, S., 2000b, Reducing prejudice and discrimination, Lawrence Erlbaum Associates, London.

Otten, S. \& Matschke, C., 2008, 'Dekategorisierung, Rekategorisierung und das Modell wechselseitiger Differenzierung' ${ }^{\prime}$ [Decategorization, recategorization and the
model of reciprocal differentiation]', in L.-E. Petersen \& B. Six (eds.), Stereotype, model of reciprocal differentiation]', in L.-E. Petersen \& B. Six (eds.), Stereotype, Vorurteile und soziale Diskriminierung: Theorien, Befunde und Interventionen
[Stereotypes, prejudices and social discrimination. Theories, findings and interventions], pp. 292-300, Beltz, Basel.

Petersen, L.-E., 2008, 'Die Theorie der sozialen Identität [The theory of social identity]', in L.-E. Petersen \& B. Six (eds.), Stereotype, Vorurteile und soziale Diskriminierung: Theorien, Befunde und Interventionen [Stereotypes, prejudices and social discrimination. Theories, findings and interventions], pp. 223-230, Beltz, Basel.

Petersen, L.-E. \& Blank, H., 2008, 'Das Paradigma der minimalen Gruppen' [The paradigm of the minimal groups], in L.-E. Petersen \& B. Six (eds.), Stereotype,
Vorurteile und soziale Diskriminierung: Theorien, Befunde und Interventionen Vorurteile und soziale Diskriminierung: Theorien, Befunde und Interventionen
[Stereotypes, prejudices and social discrimination. Theories, findings and [Stereotypes, prejudices and social discr
interventions], pp. 200-213, Beltz, Basel.

Pettigrew, T.F. \& Troop, L.R., 2000, 'Does intergroup contact reduce prejudice? Recent meta-analytic findings', in S. Oskamp (ed.), Reducing prejudice and discrimination, meta-analytic findings', in S. Oskamp (ed.), Reducing
pp. 93-114, Lawrence Erlbaum Associates, London.

Rothgangel, M., 1997, Antisemitismus als religionspädagogische Herausforderung Eine Studie unter besonderer Berücksichtigung von Röm 9-11 [Antisemitism as a religious-pedagogical challenge. A study with special consideration to Romans 9:11], Herder, Freiburg.

Schweitzer, F., 2014, Interreligiöse Bildung. Religiöse Vielfalt als religionspädagogische Herausforderung und Chance [Interreligious Education. Religious Plurality as a Challenge and Chance for Religious Education], Gütersloher Verlag, Gütersloh.

Schweitzer, F., Biesinger, A. \& Edelbrock, A. (eds.), 2008, Mein Gott - Dein Gott Interkulturelle und interreligiöse Bildung in Kindertagesstätten [My god - your god. Intercultural and interreligious education daycare centers], Beltz, Basel.

Seel, N.M., 2000, Psychologie des Lernens [Psychology of learning], UTB, München.

Selznick, G.J. \& Steinberg, S., 1969, The tenacity of prejudice: Anti-Semitism in contemporary America, Harper \& Row, New York.

Six, B., 1983, 'Vorurteil' [Prejudice], in E. Lippert \& R. Wakenhut (eds.), Handwörterbuch der Politischen Psychologie (Studienbücher zur Sozialwissenschaft 46) [Concise dictionary of political psychology (Course books for social psychology 46), pp. 326-335, Westdeutscher Verlag, Opladen.

Six, U., 1988, 'Ethnische Vorurteile. Möglichkeiten und Grenzen ihrer Reduktion durch Massenmedien [Ethnic prejudices. Possibilities and limitations to their reduction through mass medial', in B. Schäfer \& F. Petermann (eds.), Vorurteile und Einstellungen. Sozialpsychologische Beiträge zum Problem sozialer Orientierung. FS R. Bergler [Prejudices and attitudes. Social psychology articles on the problem FS R. Bergler [Prejudices and attitudes. Social psychology articles on the problem
of social orientation. A commemorative volume for R. Bergler], pp. 309-345, of social orientation. A commemor
Deutscher Instituts Verlag, Cologne. 
Stroebe, W. \& Insko, C.A., 1989, 'Stereotype, prejudice and discrimination: Changing conceptions in theory and research', in D. Bar-Tal, C.F. Graumann, A.W. Kruglanski \&
W. Stroebe (eds.), Stereotyping and prejudice. Changing conceptions, pp. 3-34, W. Stroebe (eds.), Ster.
Springer, New York.

Stürmer, S., 2008, 'Die Kontakthypothese' [The contact hypothesis], in L.-E. Petersen \& B. Six (eds.), Stereotype, Vorurteile und soziale Diskriminierung: Theorien, Befunde und Interventionen [Stereotypes, prejudices and social discrimination. Theories, findings and interventions], pp. 283-291, Beltz, Basel.

Tajfel, H., 1969, 'Cognitive aspects of prejudice', Journal of Social Issues 25, 79-97.

Tajfel, H., 1982, Gruppenkonflikt und Vorurteil. Entstehung und Funktion sozialer Stereotypen. Mit einem Vorwort von W. Stroebe [Group conflict and prejudice. Formation and function of social stereotypes, [foreword by W. Stroebe], Huber Vienna.

Wagner, U. \& Farhan, T., 2008, 'Programme zur Prävention und Veränderung von Vorurteilen gegenüber Minderheiten' [Program for the prevention and changing Vorurteile und soziale Diskriminierung: Theorien, Befunde und Interventionen
[Stereotypes, prejudices and social discrimination. Theories, findings and interventions], pp. 273-282, Beltz, Basel.

Weiss, H., 1986, 'Antisemitische Vorurteile in Österreich nach 1945. Ergebnisse empirischer Forschungen' [Antisemitic prejudices in Austria after 1945. Results of empirical research], in A. Silbermann \& J.H. Schoeps (eds.), Antisemitismus nach dem Holocaust Bestandsaufnahme und Erscheinungsformen in deutschsprachigen dem Holocaust. Bestandsaufnahme und Exscheinungsformen in deutschsprachigen p. $53-70$, German-speaking col Cologne.

Willems, J.,2011,Interreligiöse Kompetenz. Theoretische Grundlagen-Konzeptualisierungen - Unterrichtsmethoden [Interreligious competence. Theoretical foundations conceptualizations - teaching methods], VS Verlag für Sozialwissenschaften Wiesbaden.

Zick, A., 2008, 'Die Konflikttheorie der Theorie sozialer Identität [The conflict theory of the social identity theoryl', in T. Bonacker (ed.), Sozialwissenschaftliche Konflikttheorien. Eine Einführung [Socio-psychological conflict theories. An introduction], pp. 409-426, VS Verlag für Sozialwissenschaften, Wiesbaden. 